\title{
Toxicity of surface microlayer, subsurface water and sediment-elutriates from the German Bight: summary and conclusions
}

\author{
L. Karbe \\ Universität Hamburg - Zentrum für Meeres- und Klimaforschung, Institut für Hydrobiologie und Fischereiwissenschaft, \\ Zeiseweg 9, W-2000 Hamburg 50, Germany
}

\section{OBJECTIVES}

The objectives of the studies conducted during the Bremerhaven Workshop were

(1) to compare and to intercalibrate water quality bioassays which can be deployed under field conditions at sea, as a basis for selecting those most suited for monitoring,

(2) to measure effects within different matrices (surface microlayer, subsurface water, water from intermediate depth and sediment elutriates) by the same bioassay, at the same location, and at the same time,

(3) to compare results obtained along a pollution gradient to indicate which techniques best satisfy the various monitoring requirements.

For that reason, different types of samples were taken at a training station east of the isle of Helgoland, Stn 0 , and on a transect from the inner German Bight, an area directly influenced by River Weser and River Elbe discharges, to the northwest offshore to Dogger Bank Tails End, Stns 1 to 9 (Fig. 1). Subsamples of the same batches were analysed by the use of different types of bioassay techniques. The methods used and the results obtained are described in detail in the papers of Bening et al. (1992), Hardy \& Cleary (1992), McFadzen (1992), Thain $(1992 a, b)$ and Williams (1992).

\section{LOCAL CONDITIONS ON THE GERMAN BIGHT TRANSECT}

The German Bight is an area characterised by a strong mesoscale variability in its physical conditions.
This has to be taken into account when relating results on biological responses to what is known about contaminant concentrations in this area.

According to Becker (1992) the situation on the transect, during the workshop, was dominated by 2 water masses, separated by a frontal zone centred near Stn 4 . The water at Stns 1 to 3 can be classified as Continental Coastal (CCW) with density stratification and salinities increasing from 29 to 33.5 PSU (Practical Salinity Units). Stns 6 to 9 were characterised by unstratified high salinity water (above 34.7 PSU), considered typical Central Southern North Sea Water (NSW), and probably almost undiluted water of Atlantic origin with only small portions of continental fresh water.

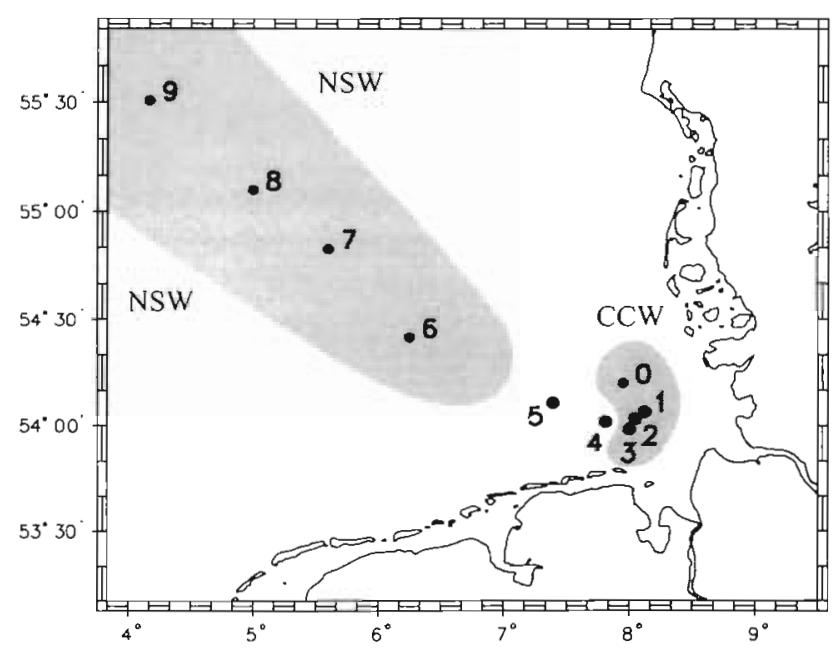

Fig. 1. Stations on the German Bight transect, dominated by continental coastal water (CCW) and southern North Sea water (NSW) nearly undiluted by freshwater discharges. The 2 areas were separated by a frontal system between Stns $4 \& 5$ 
There were only small differences between the 2 cruise legs, probably due to differences in tidal phases (Becker et al. 1992). In Table 1, salinities are listed for the standard depth, $3 \mathrm{~m}$ below surface, and $2 \mathrm{~m}$ above the bottom.

\section{SAMPLES USED FOR BIOASSAYS}

Surface microlayer. Two types of equipment were used to sample material from the surface microlayer (SMIC) at sea: Garret type screens and a teflon drum sampler (Hardy \& Cleary 1992). To deploy the sampling equipment, a rubber boat was used, driven by an electric motor. At sea, sampling was feasible only during times of day light (for safety reasons) and low wind speeds (<Beaufort 4). Due to strong winds, SMIC sampling was restricted to the training station (Stn 0) and the German Bight transect Stns 2, 4 \& 6. Additional investigations to compare the sampling efficiency of different types of samplers were conducted at a protected location within the outer harbour of Wilhelmshaven, N. Germany.

Subsurface water. Simultaneously with SMIC sampling, a water sample was taken with a glass bottle
$0.5 \mathrm{~m}$ below the surface, to compare bioassay responses to the SMIC samples and bulk water at the same locations.

Water from $3 \mathrm{~m}$ below surface. At all stations on the German Bight transect (Stns 1 to 9) water samples were taken by a rosette water sampling system connected to a CTD-Multiprobe at the same standard depth of $3 \mathrm{~m}$, which was above the pycnocline at all stations where there was density stratification.

Sediment elutriates. At all stations on the German Bight transect, sediment samples were taken by a box grab to prepare sediment elutriates. The same batch of water retrieved at $\operatorname{Stn} 7$ was used for elutriation of all the sediment samples by shaking $200 \mathrm{ml}$ of sediment with $600 \mathrm{ml}$ of sea water. After $30 \mathrm{~min}$ settlement, elutriates were filtered through a Whatman GF/C filter. The neat elutriates were tested and a subsample diluted 2.5 times with water

XAD extracts from water. During the first leg, the steaming time between the stations was used to collect large volumes of water via a continuous pumping PTFE sampling device to prepare concentrated solutions using XAD columns. On the way from Bremerhaven back to Hamburg the German Bight transect was resampled at Stns $1,5,7 \& 9$.

Table 1. Data for stations on the German Bight transect. Temperature (T) and salinity (S) $3 \mathrm{~m}$ below surface (bs) and $2 \mathrm{~m}$ above bottom (ab)

\begin{tabular}{|c|c|c|c|c|c|c|c|c|c|}
\hline Station & 1 & 2 & 3 & 4 & 5 & 6 & 7 & 8 & 9 \\
\hline \multicolumn{10}{|c|}{ RV 'Valdivia' cruise No. 94 Leg 1} \\
\hline Date & 16 Mar 90 & 17 Mar 90 & 17 Mar 90 & $17 \operatorname{Mar} 90$ & 17 Mar 90 & $18 \operatorname{Mar} 90$ & $18 \operatorname{Mar} 90$ & $18 \operatorname{Mar} 90$ & 19 Mar 90 \\
\hline $\begin{array}{l}\text { Time } \\
(\text { UTC + 1) }\end{array}$ & $20: 15$ & 06:05 & $12: 33$ & $17: 40$ & 20.55 & $05: 02$ & $13: 12$ & $18: 30$ & $00: 09$ \\
\hline Lat. $(\mathrm{N})$ & $54^{\circ} 03.90^{\prime}$ & $54^{\circ} 02.00^{\prime}$ & $53^{\circ} 59.90^{\prime}$ & $54^{\circ} 01.10^{\prime}$ & $54^{\circ} 06.50^{\prime}$ & $54^{\circ} 24.90^{\prime}$ & $54^{\circ} 49.60^{\prime}$ & $55^{\circ} 05.90^{\prime}$ & $55^{\circ} 30.50^{\prime}$ \\
\hline Long. (E) & $08^{\circ} 07.20^{\prime}$ & $08^{\circ} 02.90^{\prime}$ & $08^{\circ} 00.10^{\prime}$ & $07^{\circ} 48.80^{\prime}$ & $07^{\circ} 23.70^{\prime}$ & $06^{\circ} 15.00^{\prime}$ & $05^{\circ} 36.30^{\prime}$ & $04^{\circ} 59.90^{\prime}$ & $04^{\circ} 10.20$ \\
\hline Depth (m) & 16 & 23 & 28 & 35 & 30 & 38 & 42 & 38 & 30 \\
\hline $\begin{array}{l}\text { Wind } \\
\text { (Beaufort) }\end{array}$ & $2 / 3$ & 3 & $2 / 3$ & 0 & 3 & $3 / 4$ & $4 / 5$ & 5 & $6 / 7$ \\
\hline $\mathrm{T}\left({ }^{\circ} \mathrm{C}\right)$ bs & 6.95 & 6.64 & 6.960 & 6.84 & 7.55 & 7.15 & 7.08 & 6.96 & 7.47 \\
\hline $\mathrm{T}\left({ }^{\circ} \mathrm{C}\right) \mathrm{ab}$ & 6.63 & 6.38 & 6.41 & 6.72 & 7.37 & 7.12 & 6.90 & 6.82 & 7.47 \\
\hline $\mathrm{S}$ (PSU) bs & 28.32 & 29.60 & 29.09 & 30.99 & 34.40 & 34.87 & 34.72 & 34.73 & 35.09 \\
\hline $\mathrm{S}$ (PSU) ab & 29.76 & 31.30 & 32.43 & 33.55 & 34.91 & 34.87 & 34.68 & 34.84 & 35.08 \\
\hline \multicolumn{10}{|c|}{ RV 'Valdivia' cruise No. 94 Leg 2} \\
\hline Date & 27 Mar 90 & 27 Mar 90 & 27 Mar 90 & $27 \operatorname{Mar} 90$ & 26 Mar 90 & 21 Mar 90 & $21 \operatorname{Mar} 90$ & 22 Mar 90 & 22 Mar 90 \\
\hline $\begin{array}{l}\text { Time } \\
\text { (UTC - 1) }\end{array}$ & $10: 37^{\prime}$ & $09: 37$ & $10: 55$ & $09: 32$ & $18: 12$ & $18: 51$ & $21: 32$ & $08: 07$ & $17: 00$ \\
\hline Lat. (N) & $54^{\circ} 04.00^{\prime}$ & $54^{\circ} 02.00^{\prime}$ & $54^{\circ} 00.00^{\prime}$ & $54^{\circ} 00.30^{\prime}$ & $54^{\circ} 06.50^{\prime}$ & $54^{\circ} 24.90^{\prime}$ & $54^{\circ} 50.00^{\prime}$ & $55^{\circ} 5.90^{\prime}$ & $55^{\circ} 30^{\prime}$ \\
\hline Long. (E) & $08^{\circ} 07.70^{\prime}$ & $08^{\circ} 3.20^{\prime}$ & $08^{\circ} 00.20^{\prime}$ & $07^{\circ} 48^{\circ} 20^{\prime}$ & $07^{\circ} 24.00^{\prime}$ & $06^{\circ} 15.00^{\prime}$ & $05^{\circ} 34.90^{\prime}$ & $04^{\circ} 59.90^{\prime}$ & $04^{\circ} 10^{\prime}$ \\
\hline Depth (m) & 18 & 25 & 30 & 34 & 35 & 38 & 42 & 40 & 30 \\
\hline $\begin{array}{l}\text { Wind } \\
\text { (Beaufort) }\end{array}$ & 4 & $4 / 5$ & 4 & 5 & $3 / 4$ & 6 & 5 & $6 / 7$ & $6 / 7$ \\
\hline $\mathrm{T}\left({ }^{\circ} \mathrm{C}\right)$ bs & 7.45 & 7.29 & 7.28 & 7.10 & 7.34 & 7.34 & 7.10 & 7.01 & 7.59 \\
\hline $\mathrm{T}\left({ }^{\circ} \mathrm{C}\right) \mathrm{ab}$ & 7.09 & 7.08 & 7.15 & 7.65 & 7.76 & 7.30 & 7.11 & 7.03 & 7.59 \\
\hline $\mathrm{S}$ (PSU) bs & 28.55 & 29.14 & 30.28 & 31.28 & 32.38 & 34.85 & 34.73 & 35.05 & 35.14 \\
\hline$S$ (PSU) $a b$ & 31.59 & 32.22 & 32.57 & 33.50 & 34.21 & 34.95 & 34.71 & 35.01 & 35.09 \\
\hline
\end{tabular}




\section{PREDICTED EFFECTS}

Taking into account what is known about contaminant concentrations in the German Bight, the most toxic effects are to be expected in samples from the coastal waters influenced by continental river discharges (CCW). These are Stns 1 to 3 , and within this group of stations primarily Stn 1, which is the most influenced by the contaminant discharges of the Weser and Elbe river systems. Only minor effects were expected at Stns 6 to 9. For samples from Stns 4 \& 5, an intermediate response (or no response) was expected.

A similar regional pattern of responses was to be expected for sediment elutriates, as it is known that sediments are most contaminated at Stn 1, moderately contaminated at Stns 2 \& 3, and less at all the more offshore ones (Cofino et al. 1992). No clear predictions could be made about regional differences in surface microlayer toxicity.

\section{MEASURED EFFECTS}

In Table 2 results for the German Bight transect are summarised. They are related to the ranking of salinities, which are taken as a marker of the degree to which less contaminated North Sea water is intermixed with more contaminated continental coastal water.

Surface microlayer. SMIC samples were enriched by several metals in relation to the bulk water which varied betwen stations. The most obvious enrichment was observed for organotins including TBT, and at Stns 0 \& 4. At Stn 4 there was a period of exceptionally calm conditions and a surface film was visible. Concentrations of copper, lead, organotins and TBT decreased from inshore to offshore in both the SMIC and bulkwater.

Comparing the different sampling techniques, drum samples proved to be more chemically enriched and less diluted with underlying water. Consequently, drum samples are significantly more toxic than screen samples.

Survival of oyster and clam larvae exposed to SMIC samples from the transect increased from the more inshore to the most offshore station. However, the same trend was not apparent in the underlying bulk water. Surface microlayer contamination and toxicity related to the degree of intermixing of continental coastal with offshore North Sea water (Tables $1 \& 2$ ).

The local differences in toxicity as well as the differences between SMIC and underlying bulk water were most obvious in the responses of cryopreserved clam larvae (Fig. 1c, d in McFadzen 1992). Correlations between SMIC toxicity and contamination by in- dividual contaminants should be interpreted as covariances rather than causality.

Water. A regional pattern of 2 clusters in responses of bioassays to water samples corresponds to the distribution of water masses. The most significant regional differences in water toxicity were those of cryopreserved oyster and clam larvae. Survival of both oyster larvae and clam larvae were reduced significantly at Stns 1 to 5 and only slightly affected at the more offshore Stns 6 to 9. The data reflect the hydrography of the German Bight, with its pattern of intermixing low salinity continental coastal waters, influenced by the highly contaminated discharges from the Weser/Elbe systems, and the high salinity and less contaminated offshore Southern North Sea water (Fig. 1).

Survival of cryopreserved oyster and clam larvae was related to the salinity, which increased from 28.3-34.4 PSU at Stns 1 to 5 to above 34.7 PSU at the offshore Stns 6 to 9 . As in the case of the SMIC samples, larval growth showed a different (and less significant) response. There are indications that larval growth was influenced by differences in food supply from the natural plankton, decreasing from inshore to offshore, which may explain why the growth of the larvae was negatively correlated to their survival.

Regional differences in the trophic condition were indicated by the phytoplankton bioassays, exhibiting a high rate of reproduction at the most inshore Stns 1 to 3 where nutrient concentrations were highest. Algal reproduction continuously decreased offshore to a homogeneous group of Stns 6 to 9 .

XAD extracts. Exposure of test organisms to materials extracted from the water by use of liquid-solid adsorption to XAD columns resulted in the same pattern of responses as the cryopreserved oyster and clam larvae exposed to untreated water. Inhibition of hydroid colonial growth rates exposed to XAD resin was greatest for extracts from Stns 1 to 4 with continental coastal water, and much lower responses for Stns 6 to 9. Results were similar when the transect was resampled a week later, corroborating the hypothesis that the results were due to the 2 hydrographically distinct water masses. Bioassays on dilutions of the extracts in seawater gave a typical dose-response relationship.

Sediment elutriates. Sediment quality as indicated by bioassays of sediment elutriates followed a similar regional pattern as the water column and microlayer bioassays.

The survival and development of the bivalve and copepod larvae was generally very low in elutriates of sediments sampled at the most inshore Stn 1 (100\% mortality in the case of higher concentrations of sediment elutriated) and intermediate at Stns $2 \& 3$. Along the transect, a general increase in larval survival and development could be observed inshore to offshore, 
Table 2. Water quality bioassays: exposure to surface microlayer (SMIC) and subsurface water, water sampled from a standard depth of $3 \mathrm{~m}$, solutions obtained by liquid/solid phase extraction of water (XAD) and sediment elutriates. Trends in salinity and bioassay responses along the German Bight transect Stns 0 and 1 to 9 are indicated as increasing $(<)$ or decreasing ( $>$ ). Clusters of stations showing a similar pattern of responses that can be related to contaminant gradients in water and sediment are marked

\begin{tabular}{|c|c|c|c|c|c|c|c|c|c|c|c|c|c|c|}
\hline \multicolumn{4}{|c|}{ Water type $\quad$ Test measurement } & \multicolumn{11}{|c|}{ Response patterns } \\
\hline \multicolumn{3}{|c|}{ Salinity (\% North Sea water) } & {$[0$} & $<$ & $<$ & 2 & $<3$ & 3 ] & & $<$ & 5 & $<$ & [6 & $>7<8]<9$ \\
\hline SMIC (screen) & Cryopr. oyster larvae & survival $^{d}$ & 0 & $<$ & & 2 & & & $<4$ & & & $<$ & 6 & \\
\hline Subsurface & Cryopr. oyster larvae & survival & 0 & $<$ & & 2 & & & $=4$ & & & $=$ & 6 & \\
\hline SMIC (screen) & Cryopr. oyster larvae & length & 0 & $=$ & & 2 & & & $=4$ & & & $=$ & 6 & \\
\hline Subsurface & Cryopr. oyster larvae & length & 0 & $=$ & & 2 & & & $=4$ & & & $=$ & 6 & \\
\hline SMIC (screen) & Cryopr. clam larvae & survival $^{d}$ & 0 & $<$ & & 2 & & & $=4$ & & & $<$ & 6 & \\
\hline Subsurface & Cryopr. clam larvae & survival & 0 & $=$ & & 2 & & & $=4$ & & & $<$ & 6 & \\
\hline SMIC (screen) & Cryopr. clam larvae & length & 0 & $>$ & & 2 & & & $=4$ & & & $>$ & 6 & \\
\hline Subsurface & Cryopr. clam larvae & length & 0 & $=$ & & 2 & & & $=4$ & & & $>$ & 6 & \\
\hline SMIC (screen) & Fresh oyster embryo & developm. & 0 & $<$ & & 2 & & & $>4$ & & & $<$ & 6 & \\
\hline Subsurface (screen) & Fresh oyster embryo & developm. & 0 & $=$ & & 2 & & & $=4$ & & & $=$ & 6 & \\
\hline SMIC (drum) & Fresh oyster embryo & developm. & 0 & $<$ & & 2 & & & $>4$ & & & & & \\
\hline Subsurface (drum) & Fresh oyster embryo & developm. ${ }^{c}$ & 0 & $=$ & & 2 & & & $=2$ & & & & & \\
\hline SMIC (screen) & Copepod larvae & developm. & 0 & $<$ & & 2 & & & $=4$ & & & $>$ & 6 & \\
\hline SMIC (screen) & Copepod larvae & length & 0 & $<$ & & 2 & & & $=4$ & & & $=$ & 6 & \\
\hline Subsurface (screen) & Copepod larvae & developm. & 0 & $<$ & & 2 & & & & & & $>$ & 6 & \\
\hline Subsurface (screen) & Copepod larvae & length & 0 & $<$ & & 2 & & & $=4$ & & & $=$ & 6 & \\
\hline SMIC (drum) & Copepod larvae & developm. & 0 & $=$ & & 2 & & & $<4$ & & & & & \\
\hline SMIC (drum) & Copepod larvae & length & 0 & $=$ & & 2 & & & $<4$ & & & & & \\
\hline Subsurface (drum) & Copepod larvae & developm. & 0 & $>$ & & 2 & & & $>4$ & & & & & \\
\hline Substirface (drum) & Copepod larvae & length & 0 & $>$ & & 2 & & & $=4$ & & & & & \\
\hline Water & Cryopr oyster larvae & survival ${ }^{a}$ & & [1 & $>$ & 2 & $>3$ & & $>4$ & $=$ & $5 !$ & $<$ & 16 & $=7=8=9$ \\
\hline Water & Cryopr. oyster larvae & length & & 1 & $=$ & 2 & $=$ & 3 & $=$ & $=$ & 5 & $=$ & 6 & $=7=8=9$ \\
\hline Water & Cryopr. clam larvae & survival & & {$[1$} & $=$ & 2 & $=3$ & $\overline{3]}$ & $>\overline{4}$ & $>$ & $5]$ & $<$ & & $\overline{7}=8=9]$ \\
\hline Water & Cryopr. clam larvae & length & & {$[1$} & $<$ & 2 & $>$ & 3 & $<4]$ & $>$ & 15 & $<$ & & $7>8<9$ \\
\hline Water & Fresh oyster embryo & developm. ${ }^{\mathrm{b}}$ & & 1 & $=$ & 2 & $=$ & 3 & $=4$ & & & $=$ & 6 & $=7=8=9$ \\
\hline Water & Copepod larvae & developm. ${ }^{c}$ & & 11 & $=$ & 2 & $=$ & 3] & $>14$ & $<$ & 5 & $>$ & 6 & $<7>81>9$ \\
\hline Water & Copepod larvae & length & & {$[1$} & $=$ & 2 & $=3$ & 3 ] & $>4$ & $<$ & 5 & $<$ & 6 & $<7>8>9$ \\
\hline XAD extracts & Hydroid & reprod ${ }^{\alpha}$ & & {$[1 \ldots$} & $\ldots \ldots \ldots$ & $\ldots \ldots$. & $\ldots \ldots \ldots 3$ & & $=4$. & $\ldots \ldots$. & .51 & $<$ & 6 & . $8 \ldots \ldots \ldots \ldots$ \\
\hline XAD extracts & Hydroid & reprod. & & 1 & $<$ & & & & & & 5 & $<$ & & $7<9$ \\
\hline Sediment elut. & Cryopr. oyster larvae & survival ${ }^{d}$ & & {$[1$} & $=$ & 2 & $=$ & 3 & $=$ & $>$ & 5] & $<$ & 16 & $=7<8<9$ \\
\hline Sediment elut. & Cryopr. oyster larvae & length & & 1 & $=$ & 2 & $=$ & 3 & $=$ & $=$ & 5 & $=$ & 6 & $=7=8=9$ \\
\hline Sediment elut. & Cryopr. clam larvae & survival & & {$[1$} & $=$ & 21 & $<$ & {$[3$} & $=$ & $=$ & 5] & $<$ & 6 & $<[7=8=9]$ \\
\hline Sediment elut. & Cryopr clam larvae & length & & [1 & $=$ & 2 & $=$ & 3) & $>$ & $<$ & 5] & $>$ & 16 & $=7=8=91$ \\
\hline Sediment elut. & Fresh oyster embryo & developm. ${ }^{b}$ & & 1 & $<$ & 2 & $<3$ & 3 & $<4$ & $=$ & 5 & $>$ & 6 & $=7=8=9]$ \\
\hline Sediment elut. & Copepod larvae & survivalc & & 1 & $<$ & 2 & $=$ & 3 & $<$ & $=$ & 5 & $>$ & 6 & $<7>8<9$ \\
\hline Sediment elut. & Copepod larvae & developm. & & 1 & $<$ & 2 & $<3$ & 3. & $<4$ & $=$ & 5 & $>$ & 6 & $=7>8<9$ \\
\hline
\end{tabular}


with 2 clusters: Stns 1 to 5, and 6 to 9 . The tendency of decreasing sediment (elutriate) toxicity from inshore to offshore corresponds well with concentrations of various organic contaminants measured in the bulk sediment. The sediments exhibited a growth promoting effect (decreasing from inshore to offshore) on phytoplankton species exposed to the sediment elutriates correlated with the toxic potential of the sediment.

\section{CONCLUSIONS AND RECOMMENDATIONS}

(1) Techniques deployed are robust enough for shipboard application offshore.

(2) While varying in sensitivity, techniques are sufficiently responsive to give quantitative evidence of toxicity for a variety of sample material collected from the offshore marine environment.

(3) Regional differences in the effects of contaminants can best be investigated using samples from matrices characterized by their ability to accumulate contaminants to concentrations above the ambient water.

(4) Interfaces accumulating contaminants to higher concentrations are of particular interest. Typical examples are: the water surface microlayer enriched by contaminants due to hydrophobic interactions within the water, or by wet and dry deposition of contaminants from the atmosphere inputs; and the sediment surface layer with freshly deposited fines and decomposing organic matter. Both are sites of accummulation of organic and inorganic contaminants.

(5) The toxicity of contaminants in matrices with different sorption capacities and different bioavailabilities can be tested by their separation and concentration before being exposed to bioassay organisms.

(6) Net responses of bioassay organisms are the result of the combined and interactive effects of a complex system of factors, which are often poorly understood.

(7) Different bioassay organisms vary in their sensitivity to contaminants, so conclusions should not be based on evidence resulting from one method, but should make use of a number of different bioassay techniques simultaneously.

(8) More use should be made of sublethal indices of effect and biomarkers of effects, such as investigated in the Biochemistry and the Molecular and Cellular Pathology Group of this workshop.
(9) A reciprocal approach should be used for the practical monitoring of biological effects: field studies investigating native fish and invertebrates should be supplemented by deploying bioassay techniques using standard test organisms, such as oyster, clam or copepod larvae.

(10) It has been demonstrated that cryopreserved bioassay organisms can be used to overcome the problems of the limited seasonal availability of the biota. While cryopreserved oyster and clam larvae have been successfully used during the workshop studies, more experience is needed before use of cryopreserved material can be recommended for use in future monitoring programmes. There is some evidence that cryopreserved test organisms exhibit an increased sensitivity to contaminant stress.

(11) As differences in the condition of different batches of the same test organism may have an influence on the results, differences among the batches should be carefully evaluated. Positive and negative controls should be considered an essential component of any bioassay study.

\section{LITERATURE CITED}

Becker, G. A., Dick, S., Dippner, J. W. (1992). Hydrography of the German Bight. Mar. Ecol. Prog. Ser. 91: 9-18

Bening, J.-C., Karbe, L., Schupfner, G. (1992). Liquid/solid phase extraction of water samples used for toxicity testing in the German Bight. Mar Ecol. Prog. Ser. 91: 233-236

Cofino, W. P., Smedes, F., de Jong, S. A., Abarnou, A., Boon, J. P., Oostingh, I., Davies, l. M., Klungsoyr, J., Wilhelmsen, S., Law, R. J., Whinnett, J. A., Schmidt, D., Wilson, S. (1992). The chemistry programme. Mar. Ecol. Prog. Ser 91: $47-56$

Hardy, J T., Cleary, J. (1992). Surface microlayer contamination and toxicity in the German Bight. Mar. Ecol. Prog. Ser. 91: 203-210

McFadzen, I. (1992). Growth and survival of cryopreserved oyster and clam larvae along a pollution gradient in the German Bight. Mar. Ecol. Prog. Ser. 91: 215-220

Thain, J. (1992a). Use of the oyster Crassostrea gigas embryo bioassay on water and sediment elutriate samples from the German Bight. Mar. Ecol. Prog. Ser. 91: 21.1-213

Thain, J. (1992b). Growth of the algae Isochrysis galbana and Tetraselmis suecica in water and sediment elutriate samples from the German Bight. Mar. Ecol. Prog. Ser. 91: 229-231

Williams, T. D. (1992). Survival and development of copepod larvae Tisbe battagliai in surface microlayer, water and sediment elutriates from the German Bight. Mar. Ecol. Prog. Ser. 91: 221-228 